\title{
In Memoriam: Dr. Beverly Evans-Britt
}

\author{
Sheila Riazi, MSc, MD
}

Received: 7 November 2016/Accepted: 14 November 2016/Published online: 23 November 2016

(C) Canadian Anesthesiologists' Society 2016

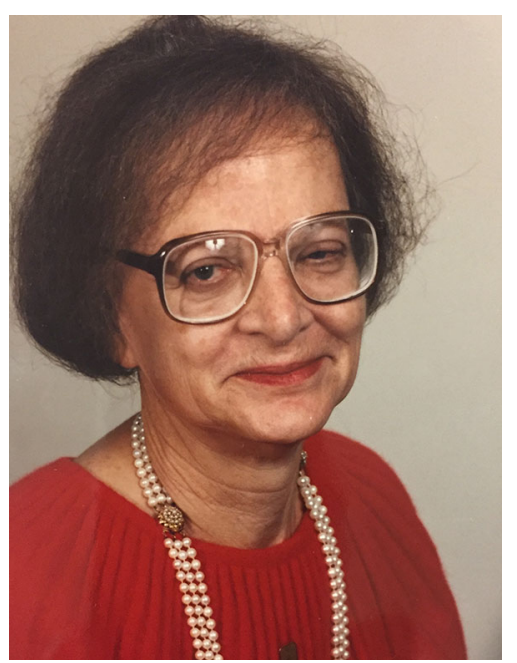

Figure Dr. Beverly Britt before her retirement from the Malignant Hyperthermia Investigation Unit (Toronto General Hospital) in 1996

Dr. Beverly Britt passed away peacefully on October 25, 2016 at her house in Wales, close to her beloved garden, after a courageous battle with cancer. Former professor of anesthesia at the University of Toronto, Dr. Britt was an internationally recognized authority on malignant hyperthermia (MH). She also worked as an anesthesiologist at Toronto General Hospital (19601996). While caring for a patient who survived an MH

S. Riazi, MSc, MD ( $\square)$

Department of Anesthesia, Toronto General Hospital, Toronto, ON, Canada

e-mail: Sheila.riazi@uhn.ca event during the early 1960s, she recognized how little was known about $\mathrm{MH}$ at the time and embarked on a career of clinical and epidemiologic studies of this potentially fatal syndrome. She partnered with a wellknown Canadian pharmacologist, Werner Kalow (19172008), to develop a preoperative diagnostic test to detect MH susceptibility. Their research was the basis for the North American caffeine-halothane contracture test and the European in vitro contracture test that are currently performed in $\mathrm{MH}$ centers around the world.

Dr. Britt introduced and worked with a porcine model of $\mathrm{MH}$ to better understand $\mathrm{MH}$ triggers and recognize the early signs of $\mathrm{MH}$. She established the MH Investigation Unit in Toronto that became the first MH diagnostic center in the world. She organized and held the first international conference on MH in Toronto in 1971 and was an enthusiastic organizer and participant of many other international meetings that focused on $\mathrm{MH}$. Her numerous papers on $\mathrm{MH}$ etiology and pathophysiology contain an enormous amount of meticulously collected data and remain a source of stimulating ideas for new generations of $\mathrm{MH}$ researchers. Dr. Britt delivered numerous talks and lectures all over the world, raising awareness of $\mathrm{MH}$ and stimulating the creation of $\mathrm{MH}$ diagnostic centers in Europe and the United States. She retired in 1996, but the MH Investigative Unit at the Toronto General Hospital that she founded continues to be one of the leading $\mathrm{MH}$ diagnostic and research centers in the world. Dr. Beverly Britt devoted her life to unraveling the biochemical and genetic causes of MH. As a result of her many contributions to the field, she remains a legend in the MH world.

She was cremated in Wales. She asked in her will that memorial donations be given to the Malignant 
Hyperthermia Education Research Innovation Fund at Toronto General Hospital, MH Investigation Unit (323200 Elizabeth Street, Toronto, ON M5G 2C4; http://pie. med.utoronto.ca/mh/MH_content/donate.html).
Conflict of Interest None declared.

Editorial responsibility This submission was handled by Dr. Hilary P. Grocott, Editor-in-Chief, Canadian Journal of Anesthesia. 